\title{
PUBLIC AID AND ENTREPRENEURSHIP DURING THE COVID-19 PANDEMIC IN THE EUROPEAN UNION COUNTRIES
}

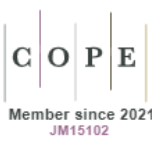

\section{Małgorzata Jabłońska* (D), Joanna Stawska**(D, Radosław Dziuba ${ }^{* * *}$, Mahmut Tekce $^{* * * *} \mathbb{D}$, Marta Krasoń ${ }^{* * * * *}$}

\begin{abstract}
The aim of the article: The outbreak of the Covid-19 pandemic made it necessary to involve the state in the process of rescuing numerous business entities from bankruptcy. In the European Union, the aid measure for entrepreneurs takes a form of public aid, which, as it turns out, is the necessary and the only tool to protect SME sector enterprises against bankruptcy. Social isolation caused by the virus that spread on a large scale effectively inhibited the development of entrepreneurship, which is inherently related to the economic development of countries. The aim of the article is therefore to indicate that supporting entrepreneurs within the framework of public aid may help to reverse the unfavorable economic trends related to the disturbed development of entrepreneurship.

Methodology: The article analyzes and assesses the government solutions introduced to the Polish economic reality, the purpose of which is to counteract the effects of Covid-19. The paper presents the current public aid tools available to entrepreneurs along with their financial dimension.

Results of the research: State aid granted by the state to entrepreneurs during the crisis caused by Covid-19 is indispensable for their further functioning. The paper presents aid instruments related to COVID-19 that are available to entrepreneurs. The analysis shows that public aid addressed to entrepreneurs injured as a result of the lockdown comes from many sources and is almost tailored to the individual entrepreneur. The entities providing aid on the basis of state aid include: banks, local government units, executive bodies of local government units, Social

*Ph.D., Assistant Professor, Faculty of Economics and Sociology, University of Lodz, e-mail: malgorzata.jablonska@uni.lodz.pl.

** Ph.D., Assistant Professor, Faculty of Economics and Sociology, University of Lodz, e-mail: joanna.stawska@uni.lodz.pl.

*** Ph.D., Assistant Professor, Faculty of Economics and Sociology, University of Lodz, e-mail: radoslaw.dziuba@uni.lodz.pl.

**** Professor, University of Marmara, Istanbul, Turkey, e-mail: mtekce@marmara.edu.tr.

***** Law student, Faculty of Law, University of Lodz, e-mail: marta-krason@o2.pl.
\end{abstract}


Insurance Fund, State Fund for Rehabilitation of Disabled People, financial intermediaries, bodies constituting local government units, the European Investment Bank, Polish Development Fund, district and voivodeship labor offices and BGK (Bank Gospodarstwa Krajowego). Having prepared a package of systemic solutions, the government introduced them systematically, depending on the situation of individual sectors of the economy. Special solutions in the form of financial shields were addressed directly to the tourism sector (e.g. loans for tour operators) or the catering sector, which in the face of the pandemic were most exposed to a decrease in revenues. The impact of introduced solutions on the country's economy can be assessed only in the next few years, but the multitude and diversified nature of the anti-crisis solutions introduced in Poland will certainly contribute to slowing down the negative consequences of Covid-19 in the economy.

Keywords: Covid-19, pandemic, public aid, SME, entrepreneurship, economy.

JEL Class: H12, H50, L21, E02. 


\section{INTRODUCTION}

Small and medium-sized enterprises are the backbone of the European economy. They represent $99 \%$ of all enterprises in the EU. They employ around 100 million people, generate more than half of Europe's GDP and play a key role in creating added value in every sector of the economy. SMEs offer innovative solutions to challenges such as climate change, resource efficiency and social cohesion, and also help spread this innovation across Europe's regions (Markovic et al., 2021). Therefore, they play a key role in the EU's dual transition to a sustainable and digital economy. They are essential for Europe's competitiveness and prosperity, industrial ecosystems, economic and technological sovereignty as well as resilience to external shocks. At the same time, they are particularly vulnerable to the effects of economic crises (including the Covid-19 pandemic) because they usually have fewer resources than large enterprise.

During the Covid-19 period, European governments tried to mitigate the economic consequences of the crisis by introducing measures to provide aid and support to businesses. A large part of them had the characteristics of public aid, which, from the point of view of the emerging global economic crisis, became the only tool that, if activated in time, could prevent the collapse of many enterprises. The nature of these measures varied across European countries, largely dependent on the need to support areas that were most exposed to negative effects of Covid-19.

The aim of this article is to indicate that sponsoring entrepreneurs as part of state aid may help reverse unfavorable economic trends related to the disturbed development of entrepreneurship. The paper was written on the basis of the literature on the field of entrepreneurship and state aid as well as using information from available websites.

\section{THE IMPORTANCE OF ENTREPRENEURSHIP FOR THE DEVELOPMENT OF THE ECONOMY}

Specialist literature indicates two main aspects of entrepreneurship. The attribute aspect, which indicates a tendency of people to function independently on the market (here, the entrepreneur's personality traits play the greatest role), and the process aspect, which is expressed in setting up one's own business (an ability to generate innovation, accept risk, etc.). In the economy, entrepreneurship is most often identified with the sector of micro, small and medium-sized enterprises, which are responsible for creating new jobs and generating gross domestic product.

Initiating entrepreneurial behavior is one of the most serious challenges for modern economies. In recent years, especially with regard to the emerging COVID-19 crisis, there are more and more people who refuse to implement plans 
to start their own business for fear of falling into even greater financial problems. Yet, some people suggest that these changes may have a positive impact, and can be a source of progress, providing learning opportunities and new business tactics (Meahjohn Inshan and Persad Prakash, 2020: 1166). Global pandemics are a serious problem for developing countries (Kobayashi et al., 2021). Therefore, it is important for the government to develop such tools to support the development of entrepreneurship that will ensure long-term and unwavering economic growth. The key role of the SME sector in economic development is often emphasized, mainly due to the GDP they generate (41.9\% in 2018, of which over $30 \%$ generated by micro-enterprises). In Poland, companies from the SME sector constitute $99.6 \%$ of all operating enterprises. The number of SMEs has grown steadily over the last few years. In 20182.15 million active non-financial enterprises operated in Poland, which constituted an increase of over 15\% compared to 2008. Service enterprises play a dominant role in SMEs (over 50\%), which contributes to the development and enrichment of society (Raport o stanie sektora małych i średnich przedsiębiorstw w Polsce, 2020: 8). It is worth noting that SMEs currently employ $68 \%$ of people working in the enterprise sector, and the monthly gross salary per 1 employee in 2018 was PLN 4,816.

Similar trends in the development of the SME sector are observed in the European Union. The analysis of data from recent years shows that the structure of Polish enterprises is slowly beginning to resemble that of the EU. The majority, i.e. $99.8 \%$ of all enterprises operating in the European Union countries are micro, small and medium-sized enterprises, yet, the structure of the SME sector itself in Poland slightly differs. In Poland, there is a tendency pointing to a higher than in the EU share of micro-enterprises in the total number of enterprises, and a number of small enterprises is almost half as big (Sektor MSP..., 2017: 12). However, if we take into account the saturation of the economy with enterprises, measured by a number of companies per 100 inhabitants, Poland looks much worse than many EU countries. In 2020, there were seven enterprises per 100 inhabitants in Poland.

The Czech Republic is the European leader - there are 13 operating companies per 100 inhabitants. The high value of this indicator is also recorded in Portugal (11), Malta (10) and Greece (12). On the other hand, the value of the entrepreneurship index that is lower than in Poland can be noted in Germany (4), Romania (4) and Austria (5). These data may indicate that Poland - taking into account the size of its population - still has a huge growth potential in terms of the number of enterprises. Perhaps, the identification of new support tools for newly established enterprises will contribute to a significant development of entrepreneurship, and thus to strengthening the economic development of Poland. 
Table 1. Index of saturation of European economies with enterprises from the SME sector in 2009-2020

\begin{tabular}{|c|c|c|c|c|c|c|c|c|c|c|c|c|}
\hline Country & 2009 & 2010 & 2011 & 2012 & 2013 & 2014 & 2015 & 2016 & 2017 & 2018 & 2019 & 2020 \\
\hline Austria & 5 & 5 & 5 & 5 & 5 & 5 & 5 & 5 & 5 & 5 & 5 & 5 \\
\hline Belgium & 7 & 7 & 7 & 8 & 8 & 8 & 8 & 8 & 8 & 8 & 8 & 8 \\
\hline Bulgaria & 7 & 6 & 6 & 6 & 7 & 7 & 7 & 7 & 7 & 7 & 7 & 7 \\
\hline Croatia & 7 & 6 & 6 & 5 & 6 & 6 & 6 & 6 & 6 & 6 & 6 & 6 \\
\hline Cyprus & 8 & 8 & 8 & 7 & 7 & 7 & 8 & 9 & 9 & 9 & 8 & 8 \\
\hline Czechia & 13 & 13 & 13 & 14 & 13 & 13 & 13 & 13 & 13 & 13 & 13 & 13 \\
\hline Denmark & 5 & 5 & 5 & 5 & 5 & 5 & 5 & 5 & 5 & 5 & 5 & 5 \\
\hline Estonia & 5 & 5 & 5 & 6 & 7 & 7 & 7 & 7 & 8 & 8 & 7 & 7 \\
\hline Finland & 6 & 6 & 6 & 6 & 6 & 6 & 6 & 6 & 6 & 6 & 6 & 6 \\
\hline France & 5 & 6 & 6 & 6 & 7 & 7 & 6 & 7 & 6 & 6 & 6 & 6 \\
\hline Germany & 3 & 3 & 4 & 4 & 4 & 4 & 4 & 4 & 4 & 4 & 4 & 4 \\
\hline Greece & 11 & 11 & 10 & 10 & 10 & 13 & 13 & 14 & 13 & 12 & 12 & 12 \\
\hline Hungary & 9 & 9 & 9 & 9 & 8 & 9 & 9 & 9 & 9 & 9 & 9 & 9 \\
\hline Ireland & 7 & 7 & 7 & 8 & 8 & 8 & 8 & 8 & 8 & 8 & 8 & 8 \\
\hline Italy & 11 & 10 & 10 & 10 & 10 & 10 & 10 & 10 & 10 & 10 & 10 & 10 \\
\hline Latvia & 5 & 5 & 5 & 7 & 7 & 8 & 8 & 8 & 8 & 8 & 7 & 7 \\
\hline Lithuania & 5 & 5 & 6 & 7 & 8 & 9 & 9 & 10 & 10 & 10 & 8 & 8 \\
\hline Luxembourg & 8 & 8 & 8 & 8 & 8 & 8 & 8 & 8 & 8 & 8 & 8 & 8 \\
\hline Malta & 12 & 12 & 11 & 11 & 10 & 10 & 9 & 10 & 9 & 10 & 10 & 10 \\
\hline Netherlands & 5 & 6 & 6 & 7 & 8 & 8 & 8 & 9 & 9 & 9 & 8 & 8 \\
\hline Poland & 6 & 6 & 6 & 6 & 6 & 6 & 7 & 7 & 7 & 8 & 7 & 7 \\
\hline Portugal & 12 & 11 & 11 & 11 & 11 & 11 & 12 & 12 & 12 & 13 & 11 & 11 \\
\hline Romania & 4 & 3 & 3 & 3 & 3 & 4 & 4 & 4 & 4 & 4 & 4 & 4 \\
\hline Slovakia & 11 & 11 & 11 & 11 & 11 & 12 & 12 & 13 & 13 & 13 & 11 & 11 \\
\hline Slovenia & 8 & 8 & 8 & 8 & 9 & 9 & 10 & 10 & 10 & 10 & 9 & 9 \\
\hline Spain & 8 & 8 & 8 & 8 & 8 & 8 & 9 & 10 & 10 & 9 & 9 & 9 \\
\hline Sweden & 8 & 8 & 9 & 9 & 9 & 9 & 9 & 9 & 9 & 8 & 9 & 9 \\
\hline
\end{tabular}

Source: own study based on Eurostat data. 


\section{STATE AID IN THE COVID-19 PANDEMIC. THEORETICAL AND PRACTICAL APPROACH}

Defining state aid is fairly complicated due to various aspects of this phenomenon. State aid is a kind of state intervention in the mechanisms of the free market (Bartniczak, 2017: 476). It is worth noting, however, that one of the goals of the European Union is to create an internal market through undistorted competition. Article 107 (1) 1 of the Treaty on the Functioning of the European Union defines public aid as: ,any aid granted by a Member State or through state resources in any form whatsoever that distorts or threatens to distort competition by favoring certain undertakings or the production of certain goods [...] to the extent that which affects trade between Member States" (Zawiadomienie Komisji w sprawie pojęcia pomocy państwa w rozumieniu art. 107...). State aid is any interference by state institutions in the functioning of enterprises (Wyrok Trybunału Sprawiedliwości z dnia 12 września 2000 r., pkt 74; Wyrok Trybunału Sprawiedliwości z dnia 10 stycznia 2006 r., pkt 107). In this context, it should be emphasized that enterprises have been defined by the Court of Justice as entities engaged in an economic activity, regardless of their legal status and the way in which they are financed. It is important that the status of an entity as an enterprise can be perceived differently under the national and the EU law. The condition for the recognition of an entity as an enterprise is that it carries out economic activity, which the Court of Justice has defined as: ,any activity consisting in offering goods and services on the market" (Wyrok Trybunału Sprawiedliwości z dnia 16 czerwca 1987 r., pkt 7; Wyrok Trybunału Sprawiedliwości z dnia 18 czerwca 1998 r., pkt 36; Wyrok Trybunału Sprawiedliwości z dnia 12 września 2000 r., pkt 7), thus making a profit by the entity is not a determinant of its classification as an enterprise.

Aid granted by the state (state aid) is a multidimensional concept, consisting of: funds granted by public central, local or regional authorities, support from state or private institutions acting on behalf of the state, funds from foreign sources controlled by the state. If a Member State is obliged to implement a measure under a European Union Directive, which leaves no margin of appreciation, the measure cannot be attributed to the Member State. In this case, the measure results from an act of the EU legislation and is not granted by the state (Wyrok Trybunału Sprawiedliwości z dnia 23 kwietnia 2009 r., pkt 70; Wyrok Sądu z dnia 5 kwietnia 2006 r., pkt 102). However, in situations where the EU law allows for certain national measures and leaves the freedom to adopt the measures to a Member State, they can be attributed to that state.

The EU aid is a concept of European law and can only be interpreted at its level. Among the EU legal acts, several types of aid can be distinguished: sectoral aid, regional aid and horizontal aid. 
Regional aid supports investment and job creation in the least developed regions. Sectoral aid is provided only to entrepreneurs from specific economic sectors, or in sensitive sectors (coal industry, steel industry, shipbuilding industry). Horizontal aid, the most general one, is addressed to all entrepreneurs, regardless of the place of business and economic sector, in order to solve a specific problem. This aid is granted, for example, to: saving and restructuring enterprises in difficulty; research, development and innovation; development of small and medium-sized enterprises; employment; services of general economic interest; providing venture capital; environmental protection and training (UOKiK).

The COVID-19 outbreak posed a serious challenge to governments around the world (Hu et al., 2021), although entrepreneurs faced similar events during the 2008-2009 financial crisis. At that time, in the EU countries there was a need to temporarily increase the fiscal capacity of the EU, which would allow for the coordinated delivery of rescue packages, both for troubled financial institutions and the Member States (Adam and Alarifi, 2021: 15). Experience from previous crises caused a change in the approach to managing economies when they occurred. It is already known that during a crisis, the lack of an effective crisis management mechanism and uncoordinated actions taken by individual countries will only increase tensions in the markets (Grondys et al., 2021: 4183). Therefore, during the recent financial crisis, after the ECB (European Central Bank) announced the Outright Monetary Transactions (OMT) program and launched it in Q3 2012, the process of restoring stability to financial markets was initiated. Further decisions to restore stability include the ECB's launch of the Quantitative Easing $(\mathrm{QE})$ program or the decision to establish the European banking union. Therefore, in the final stage of the crisis, the ECB decided to (ECB, Monetary...):

- introduce a negative interest rate on the deposit facility;

- direct the so-called Targeted Longer-Term Refinancing Operations (TLTROs) to support bank loans to enterprises and households;

- strive to support the pressure to lower the term structure of interest rates through the Asset Purchase Programs (APP),

- cover securities of the private and public sector, future.

- introduce Forward Guidance to communicate its policy shape in the

In the current crisis caused by the COVID-19 pandemic, the ECB has announced the Pandemic Emergency Purchase Program (PEPP) worth of EUR 1,350 billion. By introducing this program, the ECB aimed to lower borrowing costs and increase lending in the euro area. The ECB's introduction of PEPP in response to the COVID-19 crisis was intended to help citizens, businesses and 
governments gain access to the funds they may need to survive. In turn, as part of the EU aid in 2020, the rules for the operation of the EU Reconstruction Fund were adopted in order to mitigate the effects of the COVID-19 crisis. The budget of the program is EUR 750 billion. In addition, a long-term EU budget of EUR 1074.3 billion has also been agreed for the period 2021-2017, which will also support investments in digital and green transformation. In total, together with EUR 540 billion that has been earmarked for the security for workers, businesses and member states, the total EU recovery package is set at EUR 2,364.3 billion. This is called reconstruction plan for Europe (after the COVID-19 pandemic) (Czechowska et al., 2020: 47).

Currently, in the time of the COVID-19 pandemic, state aid in Poland has changed its character to universal. Its inevitability and necessity result from an enormous scale of threats posed by the government decisions, resulting in longterm restrictions on the free conduct of business activity. A survey conducted among 5,206 entrepreneurs in 23 countries (in the period from April to August 2020) (Stephan et al., 2021), showed that as many as $61 \%$ of entrepreneurs considered the very existence of their business to be at risk due to a significant decline in commercial activity during the Covid-19 pandemic. The respondents indicated that they had problems with entrepreneurs regarding timely debt collection ( $28 \%$ of respondents) and with the timely payment of liabilities related to the company's operations (27\%). About two-fifths of entrepreneurs (42\%) increased remote work or started working from home. A third (33\%) were still working at their company's premises, and a fifth $(20 \%)$ were already working from home before the pandemic. Approximately $26 \%$ of entrepreneurs did not notice any change. The period of the pandemic has revised the entrepreneurial ideas of business owners, as many as $68 \%$ of the surveyed entrepreneurs adjusted their business plans to the situation, and almost $40 \%$ of entrepreneurs saw new business opportunities during the pandemic. Almost half of entrepreneurs (46\%) believe that the pandemic may have a positive effect on their business in the long run.

During the pandemic, most European governments (including Poland) focused on aid measures, providing financial support to various sectors of the economy (Dhewanto et al., 2020: 218-225). They were used mainly by SMEs and micro-enterprises.

The most important categories of aid addressed by the Polish government to entrepreneurs include:

- subsidies to interest on loans,

- redeemable loans to cover the running costs of running a business for microenterprises,

- real estate tax exemption, 
- discounts in payments for rent / lease / use,

- relief in civil law receivables,

- exemption from the obligation to pay unpaid social security contributions,

- a financial shield for micro, small and medium-sized enterprises,

- additional standstill benefits and exemption from the obligation to pay due contributions for social insurance, health insurance, the Labor Fund, the Solidarity Fund, the Guaranteed Employee Benefits Fund or the Bridging Retirement Pension Fund,

- Financial and Crisis Shields for SMEs,

- one-off additional standstill benefit and exemption from the obligation to pay contributions,

- subsidies to cover the running costs of running a business for microentrepreneurs and small entrepreneurs from the Labor Fund (industry) (Chen et al., 2021),

- assistance in the form of a loan to cover the running costs of running a business for non-governmental organizations and public benefit organizations as well as co-financing the salaries of church employees of legal entities,

- liquidity loans (preferential loans (Shield for large enterprises)),

- loans for tour operators (tourism shield),

- aid for research and development activities related to the COVID-19 pandemic,

- investment aid for infrastructure to test and prepare for mass production of products to combat the COVID-19 pandemic and investment aid for the production of products to combat the COVID-19 pandemic,

- extension of real estate tax installments,

- deferral and spreading into installments of tax provided on the basis of the Tax Ordinance Act,

- co-financing a part of the costs of employees' salaries and social security contributions for SMEs,

- co-financing of a part of the costs of running a business for entrepreneurs who are natural persons and do not employ any workers,

- co-financing a part of the costs of employee salaries and social security contributions for non-governmental organizations and public benefit organizations.

The most common of the instruments presented above are funds from the so-called Financial Shield. This instrument was established by the Polish government in 2020 to stabilize the Polish economy, which was exposed to the Covid-19 crisis. The value of support offered under the Anti-Crisis Shield and the Financial Shield will amount to over PLN 312 billion over the entire period. 
Table 2. Distribution of funds from the Financial and Anti-Crisis Shield for Polish enterprises

\begin{tabular}{|c|c|c|}
\hline \multicolumn{3}{|c|}{ List of aid instruments related to COVID-19 (as of July 2021) } \\
\hline Instrument name & $\begin{array}{l}\text { The entity granting } \\
\text { the aid }\end{array}$ & Aid limit \\
\hline Interest subsidies on loans & Banks & $\begin{array}{l}\text { EUR } 100 \text { thous./ } \\
\text { EUR } 120 \text { thous./ } \\
\text { EUR } 800 \text { thous. }\end{array}$ \\
\hline $\begin{array}{l}\text { Redeemable loans to cover the running costs of } \\
\text { running a business for micro-entrepreneurs }\end{array}$ & Starosts & $\begin{array}{l}\text { EUR } 225 \text { thous./ } \\
\text { EUR } 270 \text { thous./ } \\
\text { EUR } 1,8 \text { mln }\end{array}$ \\
\hline Tax exemption on real estate & $\begin{array}{l}\text { Voyts, mayors, mayors } \\
\text { of cities }\end{array}$ & $\begin{array}{l}\text { EUR } 225 \text { thous./ } \\
\text { EUR } 270 \text { thous./ } \\
\text { EUR } 1,8 \mathrm{mln}\end{array}$ \\
\hline Subsidies for cultural institutions & $\begin{array}{l}\text { Ministry of Culture, } \\
\text { National Heritage and } \\
\text { Sports }\end{array}$ & $\begin{array}{l}\text { EUR } 225 \text { thous./ } \\
\text { EUR } 270 \text { thous./ } \\
\text { EUR } 1,8 \text { mln }\end{array}$ \\
\hline Discounts in payments for rental / lease / use & $\begin{array}{l}\text { Starosts and presidents } \\
\text { of cities with districts } \\
\text { rights }\end{array}$ & $\begin{array}{l}\text { EUR } 100 \text { thous./ } \\
\text { EUR } 120 \text { thous./ } \\
\text { EUR } 800 \text { thous. }\end{array}$ \\
\hline Discounts on receivables civil law & $\begin{array}{l}\text { Executive bodies of } \\
\text { local government units }\end{array}$ & $\begin{array}{l}\text { EUR } 100 \text { thous./ } \\
\text { EUR } 120 \text { thous/ } \\
\text { EUR } 800 \text { thous. }\end{array}$ \\
\hline Discounts in payments for rental / lease / use & $\begin{array}{l}\text { Executive bodies of } \\
\text { local government units }\end{array}$ & $\begin{array}{l}\text { EUR } 100 \text { thous./ } \\
\text { EUR } 120 \text { thous./ } \\
\text { EUR } 800 \text { thous. }\end{array}$ \\
\hline $\begin{array}{l}\text { Exemption from the obligation to pay unpaid } \\
\text { social security contributions }\end{array}$ & Social Insurance Fund & $\begin{array}{l}\text { EUR } 100 \text { thous./ } \\
\text { EUR } 120 \text { thous./ } \\
\text { EUR } 800 \text { thous. }\end{array}$ \\
\hline $\begin{array}{l}\text { Reimbursement of adaptation costs workstation } \\
\text { to your needs disabled workers for employers } \\
\text { in a difficult economic situation }\end{array}$ & $\begin{array}{l}\text { State Fund for } \\
\text { Rehabilitation of } \\
\text { Disabled People } \\
\end{array}$ & $\begin{array}{l}\text { EUR } 225 \text { thous./ } \\
\text { EUR } 270 \text { thous./ } \\
\text { EUR } 1,8 \mathrm{mln} \\
\end{array}$ \\
\hline $\begin{array}{l}\text { Monthly co-financing of employees' } \\
\text { remuneration disabled for employers in } \\
\text { a difficult economic situation }\end{array}$ & $\begin{array}{l}\text { State Fund for } \\
\text { Rehabilitation of } \\
\text { Disabled People }\end{array}$ & $\begin{array}{l}\text { EUR } 225 \text { thous./ } \\
\text { EUR } 270 \text { thous./ } \\
\text { EUR } 1,8 \mathrm{mln} \\
\end{array}$ \\
\hline $\begin{array}{l}\text { Reimbursement of the costs of hiring assistants } \\
\text { a disabled employee for employers in a difficult } \\
\text { economic situation }\end{array}$ & $\begin{array}{l}\text { State Fund for } \\
\text { Rehabilitation of } \\
\text { Disabled People }\end{array}$ & $\begin{array}{l}\text { EUR } 225 \text { thous./ } \\
\text { EUR } 270 \text { thous./ } \\
\text { EUR } 1,8 \mathrm{mln}\end{array}$ \\
\hline $\begin{array}{l}\text { Reimbursement of costs for ZCHP in difficult } \\
\text { economic situation }\end{array}$ & $\begin{array}{l}\text { State Fund for } \\
\text { Rehabilitation of } \\
\text { Disabled People } \\
\end{array}$ & $\begin{array}{l}\text { EUR } 225 \text { thous./ } \\
\text { EUR } 270 \text { thous./ } \\
\text { EUR } 1,8 \mathrm{mln} \\
\end{array}$ \\
\hline $\begin{array}{l}\text { Reimbursement of training costs disabled } \\
\text { workers for employers in a difficult economic } \\
\text { situation }\end{array}$ & $\begin{array}{l}\text { State Fund for } \\
\text { Rehabilitation of } \\
\text { Disabled People }\end{array}$ & $\begin{array}{l}\text { EUR } 225 \text { thous./ } \\
\text { EUR } 270 \text { thous./ } \\
\text { EUR } 1,8 \text { mln }\end{array}$ \\
\hline $\begin{array}{l}\text { Financial shield for micro, small and medium- } \\
\text { sized enterprises }\end{array}$ & $\begin{array}{l}\text { Polish Development } \\
\text { Fund }\end{array}$ & $\begin{array}{l}\text { EUR } 100 \text { thous./ } \\
\text { EUR } 120 \text { thous./ } \\
\text { EUR } 800 \text { thous. }\end{array}$ \\
\hline
\end{tabular}




\begin{tabular}{|c|c|c|}
\hline $\begin{array}{l}\text { Grants or repayable assistance in under } \\
\text { operational programs on 2014-2020 }\end{array}$ & Financial intermediaries & $\begin{array}{l}\text { EUR } 225 \text { thous./ } \\
\text { EUR } 270 \text { thous./ } \\
\text { EUR } 1,8 \mathrm{mln} \\
\end{array}$ \\
\hline $\begin{array}{l}\text { Public aid provided in a simplified form of } \\
\text { repayable support from the funds of financial } \\
\text { engineering instruments subject to reuse in } \\
\text { order to support the Polish economy }\end{array}$ & Financial intermediaries & $\begin{array}{l}\text { EUR } 225 \text { thous./ } \\
\text { EUR } 270 \text { thous./ } \\
\text { EUR } 1,8 \text { mln }\end{array}$ \\
\hline Reduction of the fee for perpetual usufruct & $\begin{array}{l}\text { Starosts and presidents } \\
\text { of cities with districts } \\
\text { rights }\end{array}$ & $\begin{array}{l}\text { EUR } 100 \text { thous./ } \\
\text { EUR } 120 \text { thous./ } \\
\text { EUR } 800 \text { thous. }\end{array}$ \\
\hline $\begin{array}{l}\text { Not collecting the rent and leases and usage } \\
\text { fees }\end{array}$ & $\begin{array}{l}\text { Starosts and presidents } \\
\text { of cities with districts } \\
\text { rights }\end{array}$ & $\begin{array}{l}\text { EUR } 100 \text { thous./ } \\
\text { EUR } 120 \text { thous./ } \\
\text { EUR } 800 \text { thous. }\end{array}$ \\
\hline $\begin{array}{l}\text { Reduction of the fee for perpetual usufruct, not } \\
\text { collecting the rent and leases and usage fees }\end{array}$ & $\begin{array}{l}\text { Authorities constituting } \\
\text { local government units }\end{array}$ & $\begin{array}{l}\text { EUR } 100 \text { thous./ } \\
\text { EUR } 120 \text { thous./ } \\
\text { EUR } 800 \text { thous. }\end{array}$ \\
\hline $\begin{array}{l}\text { Reduction of the perpetual usufruct fee and the } \\
\text { transformation fee for } 2021\end{array}$ & $\begin{array}{l}\text { Authorities constituting } \\
\text { local government units, } \\
\text { starosts, presidents of } \\
\text { cities with poviat rights, } \\
\text { AMW, KOWR }\end{array}$ & $\begin{array}{l}\text { EUR } 100 \text { thous./ } \\
\text { EUR } 120 \text { thous./ } \\
\text { EUR } 800 \text { thous. }\end{array}$ \\
\hline $\begin{array}{l}\text { Additional downtime benefits and exemption } \\
\text { from the obligation to pay due contributions for } \\
\text { social insurance, health insurance, Labor Fund, } \\
\text { Solidarity Fund, Guaranteed Benefits Fund } \\
\text { Employees or the Bridge Pension Fund - } \\
\text { „measures } 2 \text { and 3" }\end{array}$ & Social Insurance Fund & $\begin{array}{l}\text { EUR } 225 \text { thous./ } \\
\text { EUR } 270 \text { thous./ } \\
\text { EUR } 1,8 \text { mln }\end{array}$ \\
\hline Public aid granted by the Forests State & $\begin{array}{l}\text { Units organizational } \\
\text { structures of the State } \\
\text { Forests }\end{array}$ & $\begin{array}{l}\text { EUR } 100 \text { thous./ } \\
\text { EUR } 120 \text { thous./ } \\
\text { EUR } 800 \text { thous. }\end{array}$ \\
\hline $\begin{array}{l}\text { Pan-European Guarantee Fund in response to } \\
\text { Covid-19 }\end{array}$ & $\begin{array}{l}\text { European Investment } \\
\text { Bank }\end{array}$ & $\begin{array}{l}\text { EUR } 100 \text { thous./ } \\
\text { EUR } 120 \text { thous./ } \\
\text { EUR } 800 \text { thous. }\end{array}$ \\
\hline $\begin{array}{l}\text { Financial Shield for SMEs } 2.0 \text { (repayable } \\
\text { subsidies for micro-entrepreneurs from specific } \\
\text { industries) }\end{array}$ & $\begin{array}{l}\text { Polish Development } \\
\text { Fund }\end{array}$ & $\begin{array}{l}\text { EUR } 100 \text { thous./ } \\
\text { EUR } 120 \text { thous./ } \\
\text { EUR } 800 \text { thous. }\end{array}$ \\
\hline $\begin{array}{l}\text { One-off additional benefit parking and } \\
\text { exemption from the obligation to pay } \\
\text { contributions for November } 2020 \text { (industry) }\end{array}$ & Social Insurance Fund & $\begin{array}{l}\text { EUR } 225 \text { thous./ } \\
\text { EUR } 270 \text { thous./ } \\
\text { EUR } 1,8 \mathrm{mln}\end{array}$ \\
\hline $\begin{array}{l}\text { Subsidy to cover current business costs } \\
\text { economic for micro-entrepreneurs and small } \\
\text { entrepreneurs from the Labor Fund (industry) }\end{array}$ & Districts offices work & $\begin{array}{l}\text { EUR } 225 \text { thous./ } \\
\text { EUR } 270 \text { thous./ } \\
\text { EUR } 1,8 \mathrm{mln}\end{array}$ \\
\hline $\begin{array}{l}\text { Benefit for the protection of jobs (subsidy) } \\
\text { from the funds of FGSSP (industry) }\end{array}$ & Provincial offices work & $\begin{array}{l}\text { EUR } 225 \text { thous./ } \\
\text { EUR } 270 \text { thous./ } \\
\text { EUR } 1,8 \mathrm{mln}\end{array}$ \\
\hline $\begin{array}{l}\text { Assistance in the form of a loan to cover the } \\
\text { running costs of running a business for an } \\
\text { organization non-governmental and public }\end{array}$ & Districts offices work & $\begin{array}{l}\text { EUR } 225 \text { thous./ } \\
\text { EUR } 270 \text { thous./ } \\
\text { EUR } 1,8 \mathrm{mln}\end{array}$ \\
\hline
\end{tabular}




\begin{tabular}{|c|c|c|}
\hline $\begin{array}{l}\text { benefit organizations and subsidies to the } \\
\text { salaries of employees church legal entities }\end{array}$ & & \\
\hline $\begin{array}{l}\text { Once or twice again standstill benefit and } \\
\text { exemption from the obligation to pay } \\
\text { contributions for December or December and } \\
\text { January (industry) }\end{array}$ & Social Insurance Fund & $\begin{array}{l}\text { EUR } 225 \text { thous./ } \\
\text { EUR } 270 \text { thous./ } \\
\text { EUR } 1,8 \text { mln }\end{array}$ \\
\hline $\begin{array}{l}\text { Subsidy to cover current business costs } \\
\text { economic for micro-entrepreneurs and small } \\
\text { entrepreneurs from the Labor Fund (industry) }\end{array}$ & Districts offices work & $\begin{array}{l}\text { EUR } 225 \text { thous./ } \\
\text { EUR } 270 \text { thous./ } \\
\text { EUR } 1,8 \text { mln }\end{array}$ \\
\hline $\begin{array}{l}\text { Provision for the protection of places work } \\
\text { (subsidy) from FGŚP funds (sectoral) }\end{array}$ & Provincial offices work & $\begin{array}{l}\text { EUR } 225 \text { thous./ } \\
\text { EUR } 270 \text { thous./ } \\
\text { EUR } 1,8 \mathrm{mln}\end{array}$ \\
\hline $\begin{array}{l}\text { Lease guarantees combined with the Pan- } \\
\text { European Guarantee Fund in response to } \\
\text { COVID-19 }\end{array}$ & BGK & $\begin{array}{l}\text { EUR } 100 \text { thous./ } \\
\text { EUR } 120 \text { thous./ } \\
\text { EUR } 800 \text { thous. }\end{array}$ \\
\hline $\begin{array}{l}\text { Modification of the program SA.58102 }(2020 / \\
\mathrm{N}) \text { with regard to the first measure: subsidized } \\
\text { interest rate on loans to tour operators } \\
(,, \text { measure four”) }\end{array}$ & $\begin{array}{l}\text { Insurance Guarantee } \\
\text { Fund }\end{array}$ & $\begin{array}{l}\text { EUR } 225 \text { thous./ } \\
\text { EUR } 270 \text { thous./ } \\
\text { EUR } 1,8 \mathrm{mln}\end{array}$ \\
\hline $\begin{array}{l}\text { Standstill benefit and exemption from the } \\
\text { obligation to pay contributions for a maximum } \\
\text { period December-April (industry) }\end{array}$ & Social Insurance Fund & $\begin{array}{l}\text { EUR } 225 \text { thous./ } \\
\text { EUR } 270 \text { thous./ } \\
\text { EUR } 1,8 \mathrm{mln} \\
\end{array}$ \\
\hline $\begin{array}{l}\text { Subsidy to cover current business costs for } \\
\text { micro-entrepreneurs and small entrepreneurs } \\
\text { from the funds Labor Fund, granted up to } \\
5 \text { times (industry-specific) }\end{array}$ & Districts offices work & $\begin{array}{l}\text { EUR } 225 \text { thous./ } \\
\text { EUR } 270 \text { thous./ } \\
\text { EUR } 1,8 \mathrm{mln}\end{array}$ \\
\hline $\begin{array}{l}\text { Provision for the protection of places work } \\
\text { (subsidy) from FGŚP funds granted up to } 3 \text { or } \\
6 \text { times (sectoral) }\end{array}$ & Provincial offices work & $\begin{array}{l}\text { EUR } 225 \text { thous/ } \\
\text { EUR } 270 \text { thous./ } \\
\text { EUR } 1,8 \text { mln }\end{array}$ \\
\hline Aid in the form of loan guarantees & Voivodship Marshals & $\begin{array}{l}\text { EUR } 225 \text { thous./ } \\
\text { EUR } 270 \text { thous./ } \\
\text { EUR } 1,8 \mathrm{mln}\end{array}$ \\
\hline Aid in the form of loan guarantees & BGK & - \\
\hline $\begin{array}{l}\text { State aid provided in the form of guarantees } \\
\text { financed from EU funds }\end{array}$ & Financial intermediaries & - \\
\hline $\begin{array}{l}\text { State aid granted in the form of guarantees } \\
\text { financed from financial engineering } \\
\text { instruments that are reused to support the } \\
\text { Polish economy }\end{array}$ & Financial intermediaries & - \\
\hline $\begin{array}{l}\text { Pan-European Guarantee Fund in response to } \\
\text { Covid-19 }\end{array}$ & $\begin{array}{l}\text { European Investment } \\
\text { Bank }\end{array}$ & - \\
\hline $\begin{array}{l}\text { Public aid granted in the form of loans financed } \\
\text { from EU funds }\end{array}$ & Financial intermediaries & - \\
\hline $\begin{array}{l}\text { Public aid provided in the form of loans } \\
\text { financed with financial engineering instruments } \\
\text { that are reused to support the Polish economy }\end{array}$ & Financial intermediaries & - \\
\hline Liquidity loans (Large Enterprise Shield) & $\begin{array}{l}\text { Polish Development } \\
\text { Fund }\end{array}$ & - \\
\hline
\end{tabular}




\begin{tabular}{|c|c|c|}
\hline Preferential loans (Large Enterprise Shield) & $\begin{array}{l}\text { Polish Development } \\
\text { Fund }\end{array}$ & - \\
\hline $\begin{array}{l}\text { Loans to tour operators (tourism shield ) - „first } \\
\text { measure” }\end{array}$ & $\begin{array}{l}\text { Insurance Guarantee } \\
\text { Fund }\end{array}$ & - \\
\hline $\begin{array}{l}\text { Preferential loans } 2.0 \text { (Shield for large } \\
\text { enterprises) }\end{array}$ & $\begin{array}{l}\text { Polish Development } \\
\text { Fund }\end{array}$ & - \\
\hline $\begin{array}{l}\text { Aid for research and development related to the } \\
\text { occurrence COVID-19 pandemic, help } \\
\text { investment in infrastructure for testing and } \\
\text { preparations for mass production of products to } \\
\text { combat the COVID- } 19 \text { pandemic and } \\
\text { investment aid for production eradication } \\
\text { products the COVID-19 pandemic, granted in } \\
\text { under operational programs on } 2014-2020\end{array}$ & $\begin{array}{l}\text { Implementing } \\
\text { institutions or } \\
\text { beneficiaries (project } \\
\text { partners) }\end{array}$ & - \\
\hline $\begin{array}{l}\text { Extension of the installment payment deadline } \\
\text { property tax }\end{array}$ & $\begin{array}{l}\text { Voyts, mayors, mayors } \\
\text { of cities }\end{array}$ & - \\
\hline $\begin{array}{l}\text { Deferrals and spreads into tax installments } \\
\text { provided on the basis of the Tax Ordinance }\end{array}$ & $\begin{array}{l}\text { National and municipal } \\
\text { tax authorities }\end{array}$ & - \\
\hline $\begin{array}{l}\text { Co-financing a part of the costs of employee } \\
\text { salaries and social security contributions for } \\
\text { SMEs }\end{array}$ & Starosts & - \\
\hline $\begin{array}{l}\text { Co-financing part of the costs of running } \\
\text { a business for entrepreneurs who are natural } \\
\text { persons with no employees }\end{array}$ & Starosts & - \\
\hline $\begin{array}{l}\text { Co-financing a part of the costs of employee } \\
\text { salaries and social security contributions for } \\
\text { non-governmental organizations and public } \\
\text { benefit organization }\end{array}$ & Starosts & - \\
\hline $\begin{array}{l}\text { Financial Shield for Large Enterprises - Capital } \\
\text { Investments }\end{array}$ & $\begin{array}{l}\text { Polish Development } \\
\text { Fund }\end{array}$ & - \\
\hline $\begin{array}{l}\text { Financial Shield for SMEs } 2.0 \text { (subsidies to } \\
\text { cover uncovered part of fixed costs for } \\
\text { enterprises in specific industries) }\end{array}$ & $\begin{array}{l}\text { Polish Development } \\
\text { Fund }\end{array}$ & - \\
\hline $\begin{array}{l}\text { Cancellation of preferential loans (Large } \\
\text { Enterprise Shield) }\end{array}$ & $\begin{array}{l}\text { Polish Development } \\
\text { Fund }\end{array}$ & - \\
\hline Aid program for Polish airports & $\begin{array}{l}\text { Ministry of } \\
\text { Infrastructure }\end{array}$ & - \\
\hline $\begin{array}{l}\text { Cancellation of preferential loans } 2.0 \text { (Large } \\
\text { Enterprise Shield) }\end{array}$ & $\begin{array}{l}\text { Polish Development } \\
\text { Fund }\end{array}$ & - \\
\hline $\begin{array}{l}\text { Polish anti-crisis measures - Covid-19- } \\
\text { factoring guarantees }\end{array}$ & BGK & - \\
\hline $\begin{array}{l}\text { Polish anti-crisis measures - Covid-19- } \\
\text { insurance of trade receivables }\end{array}$ & $\begin{array}{l}\text { Ministry of } \\
\text { Development and } \\
\text { Technology }\end{array}$ & - \\
\hline
\end{tabular}

Source: Lista instrumentów pomocowych...; https://www.gov.pl/web/tarczaantykryzysowa, [Accessed 26.06.2021]. 
The PDF (Polish Development Fund - PDF) financial shield is part of the anti-crisis shield program. In the years 2020-2021, there are two versions of this instrument: PDF 1.0 and PDF 2.0. More than 347,000 enterprises have benefited from the PDF 1.0 Financial Shield program for micro, small and medium-sized enterprises from all over Poland. They employed over 3.2 million people and received support in the form of financial subsidies for a total amount of PLN 60.5 billion. In the face of the second wave of the pandemic, the government and PDF prepared the aforementioned Financial Shield 2.0. This is a new program of financial support in the form of subsidies redeemable up to $100 \%$ for companies from almost 40 industries that had to reduce or close their operations due to Covid-19. All solutions presented under the Financial Shield are aimed at:

- improving the financial liquidity of companies;

- compensating them for any damage suffered as a result of the pandemic;

- protecting jobs, especially in micro-enterprises and SMEs;

- supporting the performance of the sectors most affected by the pandemic.

The Polish government currently has a wide range of tools to help Polish entrepreneurs. The most important and, at the same time, the most promoted by the government is the package of measures introduced in March 2020 entitled „Anti-Crisis Shield" (worth of PLN 43-50 billion), about 2\% of GDP under which support is provided for business entities, households, the health care sector and the financial system. The program of financial support for enterprises was launched, worth of PLN 100 billion (about 4\% of GDP), implemented by the Polish Development Fund. As a result, after the entry into force of the first part of the aid package prepared by the government, subsequent parts of the anti-crisis shield were introduced (Table 3 ).

The intensifying crisis situation caused by the pandemic creates different business opportunities for global concerns, large and medium-sized enterprises, as well as for small companies, usually with local functions. For a company, when starting a business, an important issue are the sources of financial support, which are represented by financial institutions or the state budget. The size of the budget allows to a large extent to stimulate the economic activity of enterprises as well as to activate the market for selling products. 
Table 3. Versions of the anti-crisis shield introduced by the Polish government

\begin{tabular}{|c|c|c|}
\hline \begin{tabular}{|c|}
$\begin{array}{c}\text { Anti-Crisis Shield } \\
\text { version }\end{array}$ \\
\end{tabular} & Main assumptions & Introduction period \\
\hline, $3.0 "$ and ,4.0" & $\begin{array}{l}\text { - Easing the financial rule, which meant that local } \\
\text { governments would be able to get into more debt; } \\
\text { - Richer local governments did not have to pay } \\
\text { installments of the so-called, ,Janosikowy” in June } \\
\text { and July 2020; } \\
\text { - A credit holiday was announced, suspending loan } \\
\text { repayment up to } 3 \text { months; } \\
\text { - Facilitating tenders in the time of a pandemic; } \\
\text { - Loans, sureties and guarantees for investment and } \\
\text { operational purposes; } \\
\text { - The packages were intended to prevent job losses, } \\
\text { bankruptcies, plant closures, and a reduction in } \\
\text { business turnover and income, and much more. }\end{array}$ & $\begin{array}{ll}15.05 .2020 & (, 3.0 ”) \\
24.06 .2020 & (, 4.0 ”)\end{array}$ \\
\hline, $5.0 ”$ & $\begin{array}{l}\text { - Industry Shield; } \\
\text { - As part of this Shield, support was offered to } \\
\text { activities that were significantly affected by the } \\
\text { effects of the COVID-19 pandemic, i.e. companies } \\
\text { from the tourism and hotel sectors, as well as the } \\
\text { organization and service of fairs, conferences and } \\
\text { exhibitions; } \\
\text { - Enterprises operating in the tourism, stage and } \\
\text { exhibition industries that meet certain conditions } \\
\text { could apply for exemption from Social Insurance } \\
\text { Fund contributions or for parking benefits. }\end{array}$ & 23.09 .2020 \\
\hline, $6.0 ”$ & $\begin{array}{l}\text { - Subsequent exemptions from Social Insurance Fund; } \\
\text { - Additional downtime benefits, the so-called a small } \\
\text { subsidy of PLN 5,000, co-financing of jobs from the } \\
\text { Employee Benefit Guarantee Fund in the amount of } \\
\text { PLN 2,000 zloty or compensation for municipalities } \\
\text { in connection with lost revenues from the market fee. }\end{array}$ & 15.12 .2020 \\
\hline, $7.0 ”$ & \begin{tabular}{|l} 
It includes downtime benefits, salary subsidies, \\
subsidies to cover running costs of operations, \\
exemptions from paying Social Insurance Fund \\
contributions for December 2020 and January 2021.
\end{tabular} & 01.02 .2021 \\
\hline, $8.0 ”$ & $\begin{array}{l}\text { - Includes retirement benefits from Social Insurance } \\
\text { Fund, exemptions from Social Insurance Fund } \\
\text { contributions, subsidies to cover running costs of } \\
\text { running a business or benefits for job protection. }\end{array}$ & 28.02 .2021 \\
\hline ,9.0” & $\begin{array}{l}- \text { In the new Shield, the list of industries that may } \\
\text { benefit from the exemption from Social Insurance } \\
\text { Fund has been extended. }\end{array}$ & 16.04 .2021 \\
\hline
\end{tabular}

Source: own study based on: PWC; Ustawa z dnia 17 września 2020 r. ...; Ustawa z dnia 9 grudnia 2020 r. ...; Rozporządzenie Rady Ministrów z dnia 19 stycznia 2021 r. ...; Rozporządzenie Rady Ministrów z 26 lutego 2021 r. ... 
Measures to mitigate the negative impact of Covid-19 on the economy of the European Union (Omrani et al., 2021) have also been developed centrally by the European Commission, which has provided Member States with liquidity measures, primarily to support European small and medium-sized enterprises (SMEs). The Enterprise Europe Network (EEN) helps SMEs through innovation partnerships in areas related to COVID-19 (such as personal protective equipment and medical equipment) and advice on obtaining specific European and national financial support. In addition, the European Commission is developing a new strategy for SMEs to mitigate the effects of the Covid-19 crisis, such as: working with the EU countries to enforce the Late Payments Directive or cutting red tape. The Directorate-General for Internal Market, Industry, Entrepreneurship and SMEs plays an important role in contributing to the Commission's economic response to the outbreak, ensuring the replacement of essential protective equipment in the internal market, and helping the affected industries mitigate the effects of the outbreak. European structures are responding to the Covid-19 crisis by creating a ,recovery plan" that aims to build the resilience of Europe's supply chains and ecosystems, restore consumer and business confidence, stimulate investment and help the unemployed get back to work. The new strategy for SMEs in particular will support enterprises in sustainable and digital growth after the pandemic. In Europe, the International Monetary Fund and the World Bank have provided around USD 7.7 billion in funding to low and middle-income countries for goals such as economic stabilization, supporting people's well-being, and financing internal/external deficits, of which USD 5 billion is a new deal in the Ukraine-IMF loan promise (Bondarenko, 2020: 109-112).

It is also worth mentioning the SURE Instrument among the European Union's aid programs during the pandemic - Support to mitigate Unemployment Risks in an Emergency. The purpose of this instrument is to provide financial support to European Union countries that need significant amounts of resources to combat the negative economic and social effects caused by the COVID-19 pandemic. The aid is provided in the form of a loan and the funds may be used to cover the costs of emergency expenses for maintaining employment. The SURE instrument is helping Member States to protect jobs and a way to reduce the risk of unemployment and loss of income for workers and the self-employed (SURE instrument...). 
Table 4. Value of aid received by the European Union Member States under the SURE Instrument

\begin{tabular}{|c|c|c|}
\hline Country & The proposed loan amount & Paid \\
\hline Belgium & 8,197 bn & 8,197 bn \\
\hline Bulgaria & $511 \mathrm{mln}$ & $511 \mathrm{mln}$ \\
\hline Cyprus & $604 \mathrm{mln}$ & $604 \mathrm{mln}$ \\
\hline Estonia & $230 \mathrm{mln}$ & $230 \mathrm{mln}$ \\
\hline Greece & 5,265 bn & 5,265 bn \\
\hline Spain & 21,324 bn & 21,324 bn \\
\hline Croatia & $1,02 \mathrm{bn}$ & 1,02 bn \\
\hline Hungary & $504 \mathrm{mln}$ & $504 \mathrm{mln}$ \\
\hline Ireland & $2,5 \mathrm{bn}$ & $2,05 \mathrm{bn}$ \\
\hline Italy & 27,438 bn & 27,438 bn \\
\hline Lithuania & $957 \mathrm{mln}$ & $957 \mathrm{mln}$ \\
\hline Latvia & $305 \mathrm{mln}$ & $305 \mathrm{mln}$ \\
\hline Malta & $420 \mathrm{mln}$ & $420 \mathrm{mln}$ \\
\hline Poland & $11,23 \mathrm{bn}$ & 8,236 bn \\
\hline Portugal & 5,934 bn & 5,41 bn \\
\hline Romania & 4,099 bn & 3 bn \\
\hline Slovenia & $1,113 \mathrm{bn}$ & $1,113 \mathrm{bn}$ \\
\hline Slovakia & $630 \mathrm{mln}$ & $630 \mathrm{mln}$ \\
\hline Czech Republic & 2 bn & 2 bn \\
\hline Overall & 94,3 bn & 89,6 bn \\
\hline
\end{tabular}

Source: SURE instrument...

Under the SURE aid program, 19 Member States received aid in the amount exceeding EUR 90 billion (of which approximately EUR 90 billion have already been used). The greatest aid was offered to Italy and Spain - the total value of aid amounted to almost EUR 49 billion. It was among the citizens of these two countries that a very large number of people with COVID-19 were detected, which caused economic paralysis. Many restrictions were introduced, as a result of which people could not work or lost their jobs. In terms of the amount of aid received, Poland came third and obtained support exceeding EUR 11 billion, of which it used over EUR 8 billion.

As part of the support from the structures of the European Union, one should also mention the European Guarantee Fund (EGF) and the European Investment Bank (EIB) Group, which have joined forces to generate additional funds to support entrepreneurs in the difficult period of the COVID-19 crisis. The EGF is 
a pan-European fund with a target value of $€ 25$ billion, managed by the EIB. This fund, in cooperation with market partners, is expected to provide additional financial support to pandemic economies up to EUR 200 billion. It is expected that in Poland in the next three years, preferential financial action for entrepreneurs will amount to at least PLN 20 billion, which is a significant help for Polish enterprises, especially during the COVID-19 crisis and after the pandemic (Europejski Fundusz Gwarancyjny...). To bring the economy out of the COVID-19 crisis, cooperation between national public and private institutions, regional financial institutions, enterprises and institutions at the EU level is and will be needed. J.K. Solarz and K. Waliszewski (2021), based on the experience of the economic crisis in 2008-2009 to outline actions and recommendations to overcome the effects of the pandemic.

Quoting the previously cited KING'S BUSINESS SCHOOL study, more than half of the surveyed entrepreneurs (62\%) applied for government support during the pandemic, such as job retention programs or deferred income tax. Especially in Poland $(87.6 \%)$ and France $(82.1 \%)$, entrepreneurs sought support from the government in the form of public aid tools. Public aid, which entrepreneurs take advantage of in the face of the crisis, covers the costs of restarting companies, costs of lower labor productivity after restarting as well as „,costs” of wanting to recover assets from debt incurred during the lockdown period (McDonald, 2020: 415-428). The costs in this aspect should relate to both the economy and society.

\section{CONCLUSIONS}

Public aid during the COVID-19 pandemic began to take on a wider importance. This form of entrepreneurship support, established at the level of European Union law, is currently - in the time of the COVID-19 crisis - a key element in the functioning of many enterprises, especially SMEs. This group of entrepreneurs, which is dominant, both in the EU and in individual countries, and which is particularly exposed to any economic crises, would not be able to survive without explicit support from the countries, as evidenced by the average percentage of people benefiting from public aid in the entire EU, i.e. over $60 \%$. In economies particularly affected by restrictions introduced on a large scale related to the lockdown (e.g. long-term closed areas of economic activity, curfew, etc.), such as France or Poland, much more enterprises, i.e. almost $90 \%$ of entrepreneurs, used this type of aid.

The economic situation in the world, especially in the European Union countries, also indicated other problems, not only the financial ones, i.e. quite significant disturbances in supply chains, the effects of which will be felt in the coming years. On the one hand, it is a great threat to the current functioning of 
enterprises, but at the same time, it can become an opportunity for the development of entrepreneurship in the entire European Union. European leaders and officials are also recognizing this by creating a ,recovery plan” following the COVID-19 crisis with the primary goal of building the resilience of Europe's supply chains and ecosystems. The public aid stimulated in this way should translate into an increase in investments and help the unemployed return to work. Any state aid programs opening up new possibilities for the reconstruction of the economies of individual European countries, financially supported by the EU structures, can give a significant impulse to the development of entrepreneurship.

The forms of public aid presented in the article and the analysis of the situation of entrepreneurs in the SME sector in the time of the COVID-19 crisis may be a forecast of the commencement of transformation of the economies of individual European Union countries with the use of public aid. The COVID-19 pandemic shows how ,strong” enterprises are without public aid, and how „strong" national governments are without efficiently functioning, undisturbed supply chains of enterprises. The conclusions from the above article are another proof of the need for a balance in the economy between the school of ,state intervention" and the school of ,monetarists".

\section{Funding}

This work was supported by the National Science Centre Poland, grant No. UMO-2017/26/D/HS4/00954.

\section{Disclosure statement}

The authors report no conflicts of interest.

\section{REFERENCES}

Adam, N.A. and Alarifi, G. (2021). Innovation practices for survival of small and medium enterprises (SMEs) in the COVID-19 times: the role of external support. Journal of Innovation and Entrepreneurship, 10(1), 15, doi: 10.1186/s13731-021-00156-6.

Bartniczak, B. (2017). Market Failures as Premises of Granting State Aid. Economic and Environmental Studies, 17(3).

Bondarenko, K. (2020). The Impact of the COVID-19 Pandemic: The Case of Remittance Recipient Countries12. International Organisations Research Journal, 15(3).

Chen, J., Huang, J., Su, W., Štreimikienè, D. and Baležentis, T. (2021). The challenges of COVID-19 control policies for sustainable development of business: Evidence from service industries. Technology in Society, 66,101643, doi: 10.1016/j.techsoc.2021.101643.

Czechowska, I.D., Stawska J. i Witczak R., ed. (2020). Bezpieczeństwo i stabilność system finansowego. Perspektywa makro- i mikroekonomiczna, [Security and stability of the financial system. Macro- and microeconomic perspective]. Lodz: Publishing House of the University of Lodz, p. 47. 
Dhewanto, W., Nazmuzzaman, E. and Fauzan, T.R. (2020). Cross-countries' policies comparison of supporting small and medium-sized enterprises during covid-19 pandemic, Proceedings of the European Conference on Innovation and Entrepreneurship, ECIE 2020 - September, pp. 218-225, doi: 10.34190/EIE.20.236.

ECB, Monetary policy decision, https://www.ecb.europa.eu/mopo/decisions/html/index.en.html, [Accessed 26.06.2021].

Europejski Fundusz Gwarancyjny czeka na polskie instytucje finansowe [The European Guarantee Fund is waiting for Polish financial institutions], https://www.parkiet.com/Firmy/312289861Europejski-Fundusz-Gwarancyjny-czeka-na-polskie-instytucje-finansowe.html [Accessed 27.07.2021].

Grondys, K., Ślusarczyk, O., Hussain, H.I. and Androniceanu, A. (2021). Risk assessment of the SME sector operations during the covid-19 pandemic. International Journal of Environmental Research and Public Health, 18(8), 4183, doi: 10.3390/ijerph18084183.

https://ec.europa.eu/growth/smes_en [Accessed 19.05.2021].

https://www.gov.pl/web/tarczaantykryzysowa, [Accessed 26.06.2021].

Hu, H., Yang, Y., Zhang, J. (2021). Avoiding panic during pandemics: COVID-19 and tourismrelated businesses. Tourism Management, 86, 104316, doi: 10.1016/j.tourman.2021.104316.

Kobayashi, Y., Heinrich, T., Bryant, K.A. (2021). Public support for development aid during the COVID-19 pandemic. World Development, 138.

Lista instrumentów pomocowych związanych z Covid-19, Lista_instrumentow_pomocowych_zwiazanych_z_COVID-19_stan_na_20210714.pdf [dostęp 15.08.2021].

Markovic, S., Koporcic, N., Arslanagic-Kalajdzic, M., Kadic-Maglajlic, S., Bagherzadeh, M., Islam, N. (2021). Business-to-business open innovation: COVID-19 lessons for small and medium-sized enterprises from emerging markets. Technological Forecasting and Social Change, 170 , art. no. 120883, doi: 10.1016/j.techfore.2021.120883.

McDonald, I.M. (2020). Macroeconomic Policy to Aid Recovery after Social Distancing for COVID-19. Australian Economic Review, 53(3).

Meahjohn Inshan and Persad Prakash. (2020). The Impact of COVID-19 on Entrepreneurship Globally. Journal of Economics and Business, 3(3).

Omrani, H., Modroiu, M., Lenzi, J., Omrani, B., Said, Z., Suhrcke, M., Tchicaya, A., Nguyen, N. and Parmentier, B. (2021). COVID-19 in Europe: Dataset at a sub-national level. Data In Brief, 35(106939), doi: 10.1016/j.dib.2021.106939.

PWC, https://www.pwc.pl/pl/pdf-nf/2020/formy-dofinansowania-dla-firm.pdf [dostęp 21.12.2020] oraz Tarcza $4.0 \quad z$ podpisem prezydenta $R P, \quad \mathrm{z}$ dnia $23.06 .2020 \quad$ r. $\quad$ [za:] https://www.gov.pl/web/rozwoj-praca-technologia/tarcza-40-z-podpisem-prezydenta-rp2 [dostęp 21.12.2020].

Raport o stanie sektora małych i średnich przedsiębiorstw w Polsce [Report on the condition of the sector of small and medium-sized enterprises in Poland] (2020). Warsaw: Polish Agency for Enterprise Development.

Rozporządzenie Rady Ministrów z dnia 26 lutego 2021 r. w sprawie wsparcia uczestników obrotu gospodarczego poszkodowanych wskutek pandemii COVID-19, Dz.U. 2021, poz. 371.

Rozporządzenie Rady Ministrów z dnia 19 stycznia 2021 r. w sprawie wsparcia uczestników obrotu gospodarczego poszkodowanych wskutek pandemii COVID-19, Dz.U. 2021, poz. 152.

Sektor MSP w Polsce i UE (2017). Warszawa: Polska Agencja Rozwoju Przedsiębiorczości.

Solarz, J.K i Waliszewski, K. (2021). Holistic management of the COVID-19 pandemic, edu-Libri.

Stephan, U., Zbierowski, P., Pérez-Luño, A. and Klausen A. (2021). Entrepreneurship during the Covid-19 Pandemic: A global study of entrepreneurs' challenges,resilience, and well-being, KBS Covid-19 Research Impact Papers, 4. 
SURE instrument, European Commission, https://ec.europa.eu/info/business-economy-euro/economic-and-fiscal-policy-coordination/financial-assistance-eu/funding-mechanisms-and-facilities/sure_pl [Accessed 27.07.2021].

UOKiK, EU legal acts in the field of state aid, https://www.uokik.gov.pl/ unijne_akty_prawne_w_zakresie_pomocy_publicznej.php [Accessed 19.05.2021].

Ustawa z dnia 17 września 2020 r. o zmianie ustawy o szczególnych rozwiązaniach związanych z zapobieganiem, przeciwdziałaniem i zwalczaniem COVID-19, innych chorób zakaźnych oraz wywołanych nimi sytuacji kryzysowych oraz niektórych innych ustaw, Dz.U. 2020, poz. 1639.

Ustawa z dnia 9 grudnia 2020 r. o zmianie ustawy o szczególnych rozwiązaniach związanych z zapobieganiem, przeciwdziałaniem i zwalczaniem COVID-19, innych chorób zakaźnych oraz wywołanych nimi sytuacji kryzysowych oraz niektórych innych ustaw, Dz.U. 2020, poz. 2255.

Wyrok Sądu z dnia 5 kwietnia 2006 r. w sprawie T-351/02 Deutsche Bahn AG przeciwko Komisji, ECLI:EU:T:2006:104, dotyczącej zwolnień z podatków wymaganych przez prawo unijne.

Wyrok Trybunału Sprawiedliwości z dnia 10 stycznia 2006 r. w sprawie C-222/04 Cassa di Risparmio di Firenze SpA i in., ECLI:EU:C:2006:8.

Wyrok Trybunału Sprawiedliwości z dnia 12 września 2000 r. w sprawach połączonych od C-180/98 do C-184/98 Pavlov i in., ECLI:EU:C:2000:428.

Wyrok Trybunału Sprawiedliwości z dnia 16 czerwca 1987 r. w sprawie 118/85 Komisja przeciwko Włochom, ECLI:EU: C:1987:283.

Wyrok Trybunału Sprawiedliwości z dnia 18 czerwca 1998 r. w sprawie C-35/96 Komisja przeciwko Włochom, ECLI:EU:C:1998:303.

Wyrok Trybunału Sprawiedliwości z dnia 23 kwietnia 2009 r. w sprawie C-460/07 Puffer ECLI:EU:C:2009:254, dotyczącej prawa do ulg podatkowych w ramach systemu VAT ustanowionego przez Unię Europejską.

Zawiadomienie Komisji w sprawie pojęcia pomocy państwa w rozumieniu art. 107 ust. 1 Traktatu o funkcjonowaniu Unii Europejskiej (2016/C 262/01), Dz.Urz. UE z dnia 19.07.2016 r. na podstawie wyroku Trybunału Sprawiedliwości z dnia 22 grudnia 2008 r. w sprawie C-487/06P British Aggregates przeciwko Komisji, ECLI:EU: C:2008:757, pkt 111. 